\title{
Characteristics of Lactic Acid Bacteria Isolated from Gastrointestinal Tract of Cemani Chicken and Their Potential Use as Probiotics
}

\author{
S. N. Jannaha, A. Dinoto ${ }^{\mathrm{b}}$, K. G. Wiryawan', \& I. Rusmana ${ }^{\mathrm{a}, *}$ \\ aDepartment of Biology, Faculty of Mathematics and Natural Science, Bogor Agricultural University \\ ${ }^{b}$ Research Center for Biology, Indonesian Institute of Sciences (LIPI) \\ Jln. Raya Jakarta- Bogor Km. 46, Cibinong, 16911, West Java, Indonesia \\ 'Department of Nutrition and Feed Tecnology, Faculty of Animal Science, Bogor Agricultural University. \\ "Jln. Agatis, Kampus IPB Darmaga, Bogor, 16680, West Java, Indonesia \\ (Received 09-05-2014; Reviewed 03-06-2014; Accepted 23-10-2014)
}

\begin{abstract}
The aims of this study were to screen and characterize lactic acid bacteria (LAB) isolated from gastrointestinal (GI) tract of Cemani chicken, one of Indonesian local chicken and to investigate their potential use as probiotics. LAB were isolated from GI tract using MRSA and GYPA media and incubated anaerobically. Selected LAB were determined their probiotic properties with several assays. Identification of selected LAB was based on $16 \mathrm{~S}$ rDNA sequences, morphological and biochemical characteristics. Ninety five bacteria were isolated and characterized as lactic acid bacteria (Gram positive, catalase negative, non sporeforming and acid producing). Twenty four isolates of LAB demonstrated antimicrobial activity against Escherichia coli JCM 1649 and Salmonella enteritidis B2586, and three selected isolates, i.e. CCM011, CSP004, and CVM002 showed the highest inhibition activity. The isolates had characters of high cell surface hydrophobicity and inter-isolate coaggregation ability of $\mathrm{LAB}$, high survival at low $\mathrm{pH}$, high phytase and protease activity (but no amylase and lipase activity), weak coaggregation with pathogen and no resistance to the examined antibiotics. The isolates were identified based on sequence analysis of $16 \mathrm{~S}$ rRNA gene as Lactobacillus salivarius, however, each isolate had different profiles of sugar fermentation. Therefore the three LAB isolates had potential application as probiotics for chicken.
\end{abstract}

Key words: Cemani chicken, gastrointestinal tract, lactic acid bacteria, probiotic

\section{ABSTRAK}

Tujuan penelitian ini adalah untuk menyeleksi dan mengarakterisasi bakteri asam laktat (BAL) yang diisolasi dari saluran pencernaan ayam Cemani, salah satu ayam asli Indonesia dan untuk mengetahui potensi penggunaannya sebagai probiotik. BAL diisolasi dari saluran pencernaan dengan menggunakan medium MRSA dan GYPA dan diinkubasi secara anaerobik. BAL terpilih kemudian ditentukan karakter probiotiknya melalui serangkaian percobaan. Identifikasi isolat BAL terpilih berdasarkan pada sekuen $16 \mathrm{~S}$ rDNA, karakter morfologi dan biokimianya. Sembilan puluh lima isolat diisolasi dan dikarakterisasi sebagai bakteri asam laktat (Gram positif, katalase negatif, tidak membentuk endospora dan menghasilkan asam). Dua puluh empat isolat BAL memperlihatkan aktivitas antimikrob terhadap E. coli JCM 1649 dan S. enteritidis B2586, dan tiga isolat terpilih, yaitu CCM011, CSP004, dan CVM002 menunjukkan aktivitas penghambatan yang tertinggi. Isolat-isolat tersebut mempunyai karakter pelekatan terhadap permukaan sel yang tinggi, mempunyai kemampuan koagregasi antar BAL, daya tahan yang tinggi pada $\mathrm{pH}$ rendah, menunjukkan aktivitas enzim fitase dan protease yang tinggi (tetapi tidak mempunyai aktivitas amilase dan lipase), koagregasi yang lemah terhadap bakteri patogen dan tidak resisten terhadap antibiotik uji. Isolat-isolat tersebut diidentifikasi berdasarkan analisis sekuen gen 16S rRNA sebagai Lactobacillus salivarius, tetapi tiap isolat mempunyai profil fermentasi terhadap gula yang berbeda. Ketiga isolat BAL tersebut berpotensi sebagai probiotik pada ayam.

Kata kunci: ayam cemani, saluran pencernaan, bakteri asam laktat, probiotik

*Corresponding author:

E-mail: irusmana@ipb.ac.id 


\section{INTRODUCTION}

Increasing consumption of chicken and their products contributed to an increasing use of antibiotics in a poultry farm. Antibiotics that are used to improve chicken growth performance and to protect chicken from pathogenic microorganisms are known as antibiotic growth promoters (AGPs) (Gaggia et al., 2010). However, application of AGPs in poultry can cause development of bacterial resistance to antibiotics and it can affect human health, due to the residues in chicken products. In European countries, application of AGPs in poultry feed is prohibited.

There are several potential alternative ways instead of using AGPs, one of them is using probiotics. Probiotics are live microorganisms which, when administered in adequate amount, confer a health benefit to the host $(\mathrm{FAO} / \mathrm{WHO}, 2002)$. The aims of using probiotics in chickens are to prevent and combat gastrointestinal disorders based on competitive exclusion of potentially pathogenic bacteria, such as Salmonella enteritidis and Escherichia coli, to stimulate host immune response, and to secrete antimicrobial substances (Corcionivoschi et al., 2010).

Many studies reported that LAB could be used as probiotics for chicken (Torshizi et al., 2008; Sofyan et al., 2012). LAB probiotics showed beneficial effect by inhibiting growth of pathogen bacteria, such as Escherichia coli (Istiqomah et al., 2013) and Salmonella sp (Nouri et al., 2010). LAB have been used for fermentation of certain foods, so they are non-pathogenic bacteria and recognize as GRAS (Generally Regarded as Safe) status. These bacteria are also found normally in the gastrointestinal tract of a chicken.

Probiotics using indigenous LAB isolated from gastrointestinal tract of Cemani chicken are important as potential probiotics for Indonesian local chicken. Indonesia has thirty one local chickens with various genotypic and phenotypic characteristics (Nataamijaya, 2010). Cemani chicken is one of the Indonesian local chicken that has unique characteristics with black color on the whole body including nails, tongue, comb, beak, feet, eye-balls, legs, feathers, skin, muscles, bones, and internal organs. This chicken is recognized to have high disease resistance, and high adaptability to environmental conditions (Sulandari et al., 2009; Nataamijaya, 2010). The chicken was sometimes utilized as traditional medicine (Sartika et al., 2011). Therefore, this study was conducted to screen and characterize LAB isolates from gastrointestinal (GI) tract of Cemani chicken for potential application as probiotics in chicken.

\section{MATERIALS AND METHODS}

\section{Bacterial Cultures and Growth Condition}

Two strains of intestinal pathogenic bacteria as indicators of bacterial strains (Escherichia coli JCM 1649 and Salmonella enteritidis B2586) were used in this experiment. These indicator bacterial cultures were grown in brain heart infusion broth (Becton Dickinson) at 37 ${ }^{\circ} \mathrm{C}$ for $24 \mathrm{~h}$. All strains were subcultured twice prior to experiments.

\section{Isolation of LAB}

Three healthy Cemani chickens ( 9 to 12 months old; 1.0 to $1.5 \mathrm{~kg}$ body weight) were obtained from Mranggen district, Central Java, Indonesia. Those chickens received no antibiotic-feed containing rice bran and leftover rice before experiments. The chickens lumen contents including crop, ventriculus, ileum, and cecum were collected aseptically. Lumen samples were serially diluted in $0.85 \%(\mathrm{w} / \mathrm{v})$ sterile $\mathrm{NaCl}$ solution and plated onto MRS (HiMedia Laboratories, India) agar and glucose yeast extract peptone (GYP) agar supplemented with $0.5 \%(\mathrm{w} / \mathrm{v})$ $\mathrm{CaCO}_{3}$ to distinguish acid producing bacteria. The plates were incubated in anaerobic jars (Merck, Germany) for $48 \mathrm{~h}$ at $37^{\circ} \mathrm{C}$ with Anaerocult A (Merck, Germany). After incubation, the bacterial colonies were enumerated and purified on MRS agar up to three times to obtain pure LAB isolates. All isolates were examined for colony morphology and cell shape and catalase assay. For longterm storage, the bacterial isolates were kept at $-80{ }^{\circ} \mathrm{C}$ in $20 \%$ (v/v) glycerol until further use (Guerin-Danan et al., 1999).

\section{Antimicrobial Activity Assay}

For detection of antimicrobial activity, the well diffusion assay described by Taheri et al. (2009) was performed. The cultures were grown anaerobically overnight in MRS broth at $37^{\circ} \mathrm{C}$ to achieve cell concentration of $10^{8} \mathrm{CFU} / \mathrm{mL}$. Bacterial culture, cell-free supernatant, and neutralized cell-free supernatant $(\mathrm{pH} 7.0$, added with $2 \mathrm{M} \mathrm{NaOH}$ ) of different $\mathrm{LAB}$ isolates were determined for antimicrobial activity against indicator bacterial strains. Inhibitory zones around the wells were screened for each strain after overnight incubation at 37 ${ }^{\circ} \mathrm{C}$. The experiment was carried out three times and data were displayed as the mean of radius of inhibitory zone.

\section{pH and Bile Salts Tolerance Assay}

Overnight selected LAB cultures were centrifuged at $7,500 \times g$ for $5 \mathrm{~min}$ and washed twice with sterile phosphate buffer (PBS, pH 7.0). The washed cell density were adjusted to $\mathrm{OD}_{600}=0.5-0.7$ using spectrophotometer. For $\mathrm{pH}$ tolerance assay, $1 \mathrm{~mL}$ of cell suspensions were resuspended with $5 \mathrm{~mL} \mathrm{PBS}$ at $\mathrm{pH}$ 2.0, 4.0, and 6.5, and incubated at $37^{\circ} \mathrm{C}$ for $90 \mathrm{~min}$. Meanwhile, for bile salts tolerance assay, $1 \mathrm{~mL}$ of the washed cell suspension was resuspended in the sterile PBS containing 0.05\%, $0.08 \%, 0.1 \%$, and $0.3 \%$ bile salt (Sigma) and incubated at $37{ }^{\circ} \mathrm{C}$ for $5 \mathrm{~h}$. The bacterial survival under different $\mathrm{pH}$ conditions and concentrations of bile salts were determined by plated $0.1 \mathrm{~mL}$ suspension onto MRS agar and incubated in anaerobic jars for $48 \mathrm{~h}$ at $37^{\circ} \mathrm{C}$ (Taheri et al., 2009). 


\section{Cell Surface Hydrophobicity Test}

Assay for microbial surface hydrophobicity was performed based on the adherence to the non polar solvent (Taheri et al., 2009). Cell suspensions were prepared as above and then $3 \mathrm{~mL}$ of washed cells suspensions were added with $1 \mathrm{~mL}$ of toluene and mixed by stirring on a vortex for $2 \mathrm{~min}$. The optical density of mixture was measured at $600 \mathrm{~nm}$ using spectrophotometer. Hydrophobicity was calculated as follows:

Hydrophobicity $(\%)=\left[\left(\mathrm{OD}_{600}\right.\right.$ before mixing $-\mathrm{OD}_{600}$ after mixing) $/ \mathrm{OD}_{600}$ before mixing] $\times 100$

\section{Co-Aggregation Test}

Equal volume $(2 \mathrm{~mL})$ of suspension of each indicator bacteria and the LAB isolates were placed together in a test tube and mixed by vortexing. The $\mathrm{OD}_{600}$ of the bacterial mixture was measured after incubation at $37^{\circ} \mathrm{C}$ for $5 \mathrm{~h}$ (Taheri et al., 2009). The percentage of co-aggregation was calculated by using the equation as follows:

$$
\text { Co-aggregation } \begin{aligned}
(\%)= & \left.\left\{\left[\left(\mathrm{A}_{\mathrm{x}}+\mathrm{A}_{\mathrm{y}}\right) / 2-\mathrm{A}_{(\mathrm{x}}+{ }_{\mathrm{y}}\right)\right] /\left[\left(\mathrm{A}_{\mathrm{x}}+\mathrm{A}_{\mathrm{y}}\right) / 2\right]\right\} \\
& \times 100
\end{aligned}
$$

which representing absorbance value (A) at each of the two strains examined in the control tube ( $x$ and $y)$, and at their mixture $(x+y)$.

\section{Enzymatic Activities Assay}

The selected LAB isolates were assayed for the presence of dietary enzymes, i.e. amylase, protease, lipase, and phytase (Taheri et al., 2009). To detect the amylase, lipase, and phytase activities, the isolates were subcultured in MRS broth and then spot-inoculated onto relevant agar-based media (starch agar, skim milk agar, phytic acid enriched agar and lipid hydrolysis agar). After anaerobic incubation for $48 \mathrm{~h}$ at $37^{\circ} \mathrm{C}$, a clear zone surrounding each colony was measured. Lugol's solution was added over the plate surface for clear zone detection of amylase activity.

\section{Antibiotic Sensitivity Test}

Antibiotic susceptibility of selected LAB isolates was determined by using Kirby-Bauer disc method (Taheri et al., 2009). As much as $0.1 \mathrm{~mL}$ of LAB cell suspensions were spread over the entire surface of the plates containing MRS agar. Subsequently, paper discs containing antibiotics of amoxicillin $10 \mu \mathrm{g}$, ampicillin $10 \mu \mathrm{g}$, chloramphenicol $30 \mu \mathrm{g}$, cefadroxil $30 \mu \mathrm{g}$, doxycycline $30 \mu \mathrm{g}$, erythromycin $15 \mu \mathrm{g}$, lincomycin $15 \mu \mathrm{g}$, rifampin $5 \mu \mathrm{g}$, spiramycin $30 \mu \mathrm{g}$, and tetracycline $30 \mu \mathrm{g}$ were placed on the plates and incubated anaerobically at $37^{\circ} \mathrm{C}$ for $24 \mathrm{~h}$. Diameter of a clear zone was measured to determine antibiotic sensitivity of the isolates.

\section{Identification of LAB Isolate}

Genomic DNAs from the selected LAB isolates were extracted by using Xprep Stool DNA Mini Kit (PhileKorea Technology, INC, Korea) according to the manufacturer's instructions. DNA pellet was then resuspended in $50 \mu \mathrm{L}$ TE buffer and stored at $-20{ }^{\circ} \mathrm{C}$. A PCR mixture was prepared from each sample using a TaKaRa PCR Thermal Cycler with forward primer 27F (5'AGAGTTTGATCCTGGCTCAG-3') and reverse primer 1492R (5'-GTTACGACTTCACCCTCCT-3') (Zhang, et al., 2007). PCR reaction mixture consisted of $25 \mu \mathrm{L}$ GoTaq GreenMaster Mix (Promega, USA), $2 \mu \mathrm{L}$ of each primer (10 pmol), and destilated water in a final volume of 50 $\mu \mathrm{L}$ and 100 ng DNA template in the final concentration. PCR condition was set up with an initial denaturation at $94{ }^{\circ} \mathrm{C}$ for $1 \mathrm{~min} 30 \mathrm{~s}$, followed by 25 cycles of denaturation temperature at $95{ }^{\circ} \mathrm{C}$ for $30 \mathrm{~s}$, annealing temperature of $50{ }^{\circ} \mathrm{C}$ for $30 \mathrm{~s}$, and extension temperature at 72 ${ }^{\circ} \mathrm{C}$ for $1 \mathrm{~min} 30 \mathrm{~s}$ and then final elongation at a temperature of $72{ }^{\circ} \mathrm{C}$ for $5 \mathrm{~min}$. PCR products were confirmed by electrophoresis by using $1 \%$ agarose gel in $1 \mathrm{x}$ TAE buffer and visualized with ethidium bromide staining. Purification of PCR products and sequencing were conducted by a company providing sequences services. The DNA sequences were compared with available sequences in GenBank using the BLASTN tools through the National Center for Biotechnology Information (NCBI). Sequence homology of more than $97 \%$ was regarded as belonging to the same species (Tannock, 1999). The sequence was aligned with the clustal $X$ program, then the alignment was manually edited to the construction of phylogenetic tree. The phylogenetic tree was constructed by neigbour-joining method in MEGA program version 4 . The values of branches of phylogenetic tree were determined using booststrap analysis based on 1000 resamplings (Felsenstein, 1985).

\section{Biochemical Characterization of LAB}

Biochemical characterization of the selected LAB was determined by using $\mathrm{API}^{\circledR} 50 \mathrm{CHL}$ for performance of carbohydrate metabolism tests (bioMérieux, Inc, Durham) according to the manufacturer's instructions. Fermentation profiles of the isolates were determined by using the API web software (Pelinescu et al., 2009).

\section{Statistical Analysis}

All quantitative data were subjected to ANOVA analysis by using IBM SPSS statistics 21.0. A test of least significant differences was used to separate means; differences between means were considered statistically significant $\mathrm{P}<0.05$.

\section{RESULTS AND DISCUSSION}

\section{Population of Culturable LAB in Chicken Gastrointestinal Tracts}

By culturing method, the content of gastrointestinal tract of chicken had LAB number $7.12 \pm 0.63$ up to 9.07 $\pm 0.17 \log \mathrm{CFU} \mathrm{g}^{-1}$ and the highest number was found in crop region (Table 1), followed by cecum, ileum and ventriculus, respectively. The $\mathrm{pH}$ of all regions were below 7 . The number of $\mathrm{LAB}$ was not influenced by the $\mathrm{pH}$ value. There were many other factors affecting such 
Table 1. Total culturable lactic acid bacteria incubated in MRS agar for $48 \mathrm{~h}$ and $\mathrm{pH}$ from gastrointestinal tract of Indonesian Cemani chicken

\begin{tabular}{lcc}
\hline Sample & $\log \mathrm{cfu} / \mathrm{g} \pm \mathrm{SD}(\mathrm{n}=3)$ & $\mathrm{pH} \pm \mathrm{SD}(\mathrm{n}=3)$ \\
\hline Crop & $9.07 \pm 0.17$ & $5.05 \pm 1.48$ \\
Ventriculus & $7.12 \pm 0.63$ & $4.50 \pm 0.71$ \\
Ileum & $7.25 \pm 0.22$ & $6.20 \pm 0.14$ \\
Caecum & $8.57 \pm 0.64$ & $6.55 \pm 0.64$ \\
\hline
\end{tabular}

as diet, age, presence of barrier in the intestine and different physiological functions within the organ system (Dumonceaux et al., 2006).

Ninety-five LAB colonies were randomly picked based on clear zone and colony morphology on MRSA or GYPA medium supplemented with $\mathrm{CaCO}_{3}$. All isolates had specific characteristics of lactic acid bacteria, such as positive Gram stain, catalase negative reaction and no endospore forming, and mostly bacterial cell had rod-shaped (88 isolates, 92.6\%) and 7 isolates (7.4\%) had round shaped.

\section{Assessment of Probiotic Characteristics}

For antimicrobial activity assays, Escherichia coli and Salmonella enteritidis were used, because they were common potentially intestinal pathogenic bacteria causing problem of gastro intestinal tract in chicken. Antimicrobial activity of $24 \mathrm{LAB}$ isolates against E. coli and $S$. enteritidis was shown in Table 2. All bacterial cultures had antimicrobial activity against E. coli and $S$. enteritidis, however there were only $10 \mathrm{LAB}$ isolates $(41.7 \%)$ and 7 LAB isolates $(29.2 \%)$ that their cell-free neutralized supernatant exhibited antibacterial activity against E. coli and S. enteritidis, respectively.

Three LAB isolates, i.e. CSP004, CCM011 and CVM002 that had the highest inhibition zone of their

Table 2. Number of lactic acid bacteria having antimicrobial activity against $E$. coli and $S$. enteritidis using diffusion agar test

\begin{tabular}{lccc}
\hline \multirow{2}{*}{$\begin{array}{c}\text { Bacterial } \\
\text { indicator }\end{array}$} & \multicolumn{2}{c}{$\begin{array}{c}\text { Number of lactic acid bacteria having } \\
\text { antimicrobial activity (n (\%)) from: }\end{array}$} \\
\cline { 2 - 4 } & Bacterial cell & Supernatant & $\begin{array}{c}\text { Neutralized } \\
\text { supernatant }\end{array}$ \\
\hline E. coli & $24(100)$ & $20(83.3)$ & $10(41.7)$ \\
S. enteritidis & $24(100)$ & $21(87.5)$ & $7(29.2)$ \\
\hline
\end{tabular}

cell-free neutralized supernatant were selected for further assays. The neutralized supernatant of these isolates were able to inhibit the growth of the Gram negative pathogen tested in this study. The antimicrobial activity of neutralized cell-free supernatants of CSP004 isolate to $S$. enteritidis was higher than that of non neutralized supernatant. Antimicrobial activity of neutralized supernatant of CCM011 isolate was not significantly different from that of non neutralized supernatant (Table 3). According to Nouri et al. (2010) and Heravi et al. (2011) study, L. salivarius had the highest inhibitory activity against $S$. enteritidis and E.coli.

LAB isolates showed ability to inhibit pathogen growth possibly through cell competitiveness, decreasing $\mathrm{pH}$ environment and producing organic acids and bacteriocin. Organic acids produced by LAB such as acetic and lactic acid inhibited the growth of many bacteria, especially pathogenic gram-negative types, like E. coli and $S$. enterica, due to its ability to undissociate to penetrate the cytoplasmic membrane, resulting in reduction of intracellular $\mathrm{pH}$ and disruption of the transmembrane proton motive force (Alakomi et al., 2000).

Survival assay under acid condition showed that all isolates survived at $\mathrm{pH} 4$ and $\mathrm{pH}$ 2, however, there were decreasing viability at $\mathrm{pH} 2$ comparing with control ( $\mathrm{pH}$ 6.5). The CVM002 isolate had the highest survival ability at low $\mathrm{pH}$ (Table 4). Most LAB grow more slowly at low $\mathrm{pH}$, probably caused by acid that can damage and loss of cell viability. However, LAB had ability to regulate their cytoplasmic or intracellular $\mathrm{pH}$ at near neutral during growth or storage at low extracellular $\mathrm{pH}$ (Konings et al., 1997).

Survival assay under bile salts condition showed that all isolates did not survive under $0.3 \%$ bile salts. However the isolates could survive under $0.1 \%$ bile salts. The survival of the isolates under $0.1 \%$ bile salts was decreased after 5 hours incubation at $0.1 \%$ bile salts suspension (Table 4). Iniguez-Palomares et al. (2007) reported that $\mathrm{LAB}$ isolates had no resistance to CPBS (conjugated porcine bile salts) at concentration more than $0.1 \%$ bile salt. Bile released in the small intestine, could damage bacteria because its destroying effect to cell membrane. Some bacteria, like lactic acid bacteria had bile salt hydrolase enzyme (BSH), so that had ability hydrolyzing bile salt and reducing their solubility. To enhance survival of bacterial passage through upper gastrointestinal tract could be conducted by encapsulating bacteria with alginate and skim.

One benefit of probiotics is production of extracellular enzymes supporting the host to digest their nutrients.

Table 3. Inhibitory activity of cell-free supernatants of selected lactic acid bacteria (LAB) isolates against E. coli and S. enteritidis

\begin{tabular}{ccccccc}
\hline \multirow{2}{*}{ LAB isolate } & \multirow{2}{*}{ Source of isolate } & \multicolumn{3}{c}{ Diameter of inhibitory zone (mm) against } \\
\cline { 3 - 6 } & & E. coli & & \multicolumn{2}{c}{ S. enteritidis } \\
\cline { 3 - 4 } \cline { 5 - 6 } & Crop & Untreated & Neutralized & & Untreated & Neutralized \\
\hline CCM011 & Cecum & $9.3 \pm 0.6^{\mathrm{a}}$ & $8.3 \pm 0.6^{\mathrm{a}}$ & & $7.3 \pm 1.2^{\mathrm{a}}$ & $6.3 \pm 0.6^{\mathrm{a}}$ \\
CSP004 & Gizzard & $8.3 \pm 0.6^{\mathrm{a}}$ & $5.3 \pm 1.2^{\mathrm{b}}$ & & $8.3 \pm 0.6^{\mathrm{a}}$ & $16.0 \pm 2.0^{\mathrm{b}}$ \\
CVM002 & & $3.3 \pm 1.2^{\mathrm{b}}$ & & $18.7 \pm 0.6^{\mathrm{a}}$ & $8.3 \pm 0.6^{\mathrm{b}}$ \\
\hline
\end{tabular}

Note: Means in the same row with different superscripts differ significantly $(\mathrm{P}<0.05)$ 
Table 4. Survival of selected LAB Isolates on inhibitory substances conditions

\begin{tabular}{|c|c|c|c|}
\hline \multirow{2}{*}{$\begin{array}{l}\text { Inhibitory } \\
\text { condition of }\end{array}$} & \multicolumn{3}{|c|}{ Viable LAB isolate (Log10 CFU/mL) } \\
\hline & CCM011 & CSP004 & CVM002 \\
\hline \multicolumn{4}{|l|}{$\mathrm{pH}$} \\
\hline $\mathrm{pH} 2.0$ & $5.71 \pm 0.01^{\mathrm{a}}$ & $4.68 \pm 0.03^{\mathrm{a}}$ & $5.85 \pm 0.01^{\mathrm{a}}$ \\
\hline $\mathrm{pH} 4.0$ & $6.11 \pm 0.10^{\mathrm{b}}$ & $5.79 \pm 0.01^{\mathrm{b}}$ & $6.16 \pm 0.02^{\mathrm{b}}$ \\
\hline $\mathrm{pH} 6.5$ & $6.73 \pm 0.02^{c}$ & $6.25 \pm 0.07^{c}$ & $6.2 \pm 0.040^{\mathrm{b}}$ \\
\hline \multicolumn{4}{|l|}{ Bile salts } \\
\hline $0 \%$ & $6.73 \pm 0.11^{\mathrm{a}}$ & $6.60 \pm 0.31^{\mathrm{a}}$ & $6.87 \pm 0.03^{\mathrm{a}}$ \\
\hline $0.05 \%$ & $3.68 \pm 0.06^{\mathrm{b}}$ & $4.04 \pm 0.62^{\mathrm{b}}$ & $4.04 \pm 0.37^{\mathrm{b}}$ \\
\hline $0.08 \%$ & $1.45 \pm 0.04^{c}$ & $2.39 \pm 0.30^{c}$ & $1.57 \pm 0.04^{c}$ \\
\hline $0.10 \%$ & $0.74 \pm 0.06^{\mathrm{d}}$ & $0.59 \pm 0.16^{\mathrm{d}}$ & $0.45 \pm 0.21^{\mathrm{d}}$ \\
\hline $0.30 \%$ & ND & ND & ND \\
\hline
\end{tabular}

Note: Means in the same column with different superscripts differ significantly $(\mathrm{P}<0.05) ; \mathrm{ND}=$ Not detected.

Chicken feed especially grains contains many substrates like starch, protein and fats, and other components such as mannans, cellulose, lignin and phytic acid, which are difficult to be digested by monogastric animals like chicken. API $50 \mathrm{CHL}$ assay confirmed that all isolates did not grow on starch agar (Table 5). The isolates also did not have lipase enzyme. However, the isolates could produce protease and phytase (Table 6). Musikasang et al. (2012) found that LAB isolates showed the proteinase activity, but neither starch nor lipid digestions were detected.

Selected LAB isolates can produce phytase that hydrolyzes phytic acid to myo-inositol and phosphoric acid. This enzyme is needed for chicken, because chicken do not capable to metabolize phytate phosphorus due to the lack of digestive enzymes hydrolyzing the substrate. In addition, phytic acid that is the storage form of phosphorus in cereal, oil and legume, act as an antinutritional agents forming complexes with proteins and various metal ions, thereby decreasing the dietary bioavailability of these nutrients (Raghavedra \& Halami, 2009). Bifidobacterium dentium, L. reuteri L-M15 and L. salivarius L-ID15 isolated from gastrointestinal tract of chickens showed the highest phytate degrading activity (Palacios et al., 2007).

Microbial adhesion to hydrocarbon of the LAB isolates indicated the hydrophobicity of cell surface properties. The LAB isolates exhibited high hydrophobicity that was determined by microbial adhesion to toluene in the range of $77 \%-82 \%$. The strong hydrophobicity ability was shown by CVM002 isolate. As much as $82 \%$ cells of the isolate could adhere to hydrocarbon toluen. It was suggested that CVM002 isolate showed high adhesion ability to mucus and epithelial cells in the intestine. $L$.

Table 5. Sugar fermentation pattern of selected lactic acid bacteria (LAB) isolates using API 50 CHL Kit

\begin{tabular}{|c|c|c|c|c|c|c|c|}
\hline \multirow{2}{*}{ No Substrate } & \multicolumn{3}{|c|}{ Reaction of is olates } & \multirow{2}{*}{ No Substrate } & \multicolumn{3}{|c|}{ Reaction of isolates } \\
\hline & CCM011 & CSP004 & CVM002 & & CCM011 & CSP004 & CVM002 \\
\hline 0 Control & - & - & - & 25 Esculin ferric citrat & - & - & - \\
\hline 1 Glycerol & - & - & - & 26 Salicin & - & - & - \\
\hline 2 Erythritol & - & - & - & 27 D-cellobiose & - & - & - \\
\hline 3 D-arabinose & - & - & - & 28 D-maltose & + & + & + \\
\hline 4 L-arabinose & - & - & - & 29 D-lactose (bovine origin) & - & + & + \\
\hline 5 D-ribose & - & - & - & 30 D-melibiose & - & + & + \\
\hline 6 D-xylose & - & - & - & 31 Saccharose (sucrose) & + & + & + \\
\hline 7 L-xylose & & & & 32 D-trehalose & + & + & + \\
\hline 8 D-adonitol & - & - & - & 33 Inulin & - & - & - \\
\hline 9 Methyl- $\beta$-d xylopyranoside & - & - & - & 34 D-melezitose & - & - & - \\
\hline 10 D-galaktose & - & + & + & 35 D-raffinose & - & + & + \\
\hline 11 D-glukose & + & + & + & 36 Amidon (starch) & - & - & - \\
\hline 12 D-fructose & + & + & + & 37 Glycogen & - & - & - \\
\hline 13 D-manose & + & + & + & 38 Xylitol & - & - & + \\
\hline 14 L-sorbose & - & - & - & 39 Gentiobiose & - & - & - \\
\hline 15 L-rhamnose & - & - & + & 40 D-turanose & - & - & - \\
\hline 16 Dulcitol & - & - & - & 41 D-lyxose & - & - & - \\
\hline 17 Inositol & - & + & - & 42 D-tagatose & - & - & - \\
\hline 18 D-mannitol & + & + & + & 43 D-fucose & - & - & - \\
\hline 19 D-sorbitol & + & + & + & 44 L-fucose & - & - & - \\
\hline 20 Methyl- $\alpha$-d mannopyranoside & - & - & - & 45 D-arabitol & - & - & + \\
\hline 21 Methyl- $\alpha$-d glucopyranoside & - & - & - & 46 L-arabitol & - & - & - \\
\hline 22 N-acetyl glucosamine & + & + & + & 47 Potasiumgluconat & - & - & - \\
\hline 23 Amygdalyn & - & - & - & 48 Potasium 2-keto-gluconat & - & - & - \\
\hline 24 Arbutin & - & - & - & 49 Potasium 5-keto-gluconat & - & - & - \\
\hline
\end{tabular}


Table 6. Enzymatic activities of selected lactic acid bacteria (LAB) isolates

\begin{tabular}{lccc}
\hline \multirow{2}{*}{ Enzyme } & \multicolumn{3}{c}{ LAB isolate } \\
\cline { 2 - 4 } & CCM011 & CSP004 & CVM002 \\
\hline Amylase & - & - & - \\
Protease & ++ & ++ & +++ \\
Phytase & +++ & +++ & ++ \\
Lipase & - & - & - \\
\hline
\end{tabular}

Note: $+++=$ clear zone $\geq 3 \mathrm{~mm} ;++=$ clear zone $\leq 3 \mathrm{~mm} ;-=$ not detected.

salivarius has capability to produce bacteriosin and exopolysaccaharide (EPS) that helps to adhere to intestinal mucus (Raftis et al., 2011). The ability of bacteria to produce biofilm and adhesion are able to increase the gut residence time of commensal bacteria and promote pathogen exclusion.

Inter-isolate coaggregation ability of $\mathrm{LAB}$ was needed to evaluate the effectiveness of probiotics adhesion in the intestine. Meanwhile, coaggregation between $\mathrm{LAB}$ isolates and bacterial pathogens to avoid adhesion of pathogen on host intestinal cells. Inter-isolate coaggregation of $\mathrm{LAB}$ was from $26.64 \%$ to $81.56 \%$, and the highest coaggregation was found on CSP004 and CVM002 isolates (Figure 1). Coaggregation ability between pathogenic bacteria, E. coli and CCM011 isolates showed weak coaggregation, however there was no coaggregation of

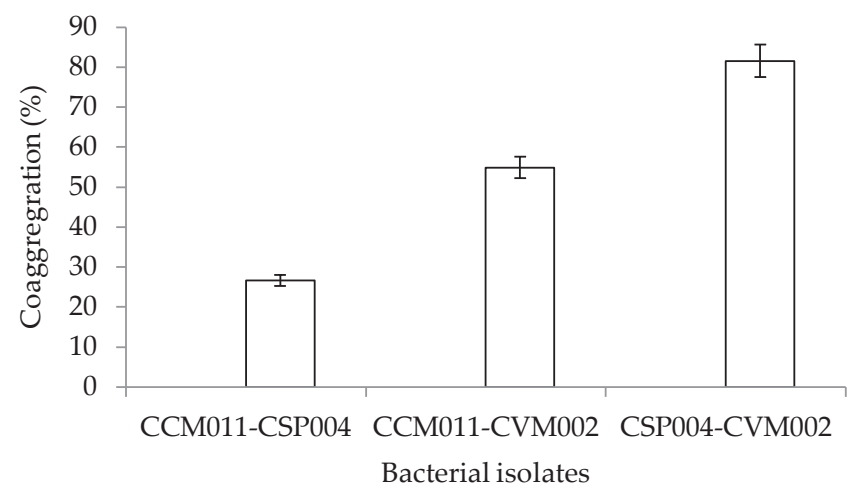

Figure 1. Inter-isolate coaggregation ability of the LAB isolates

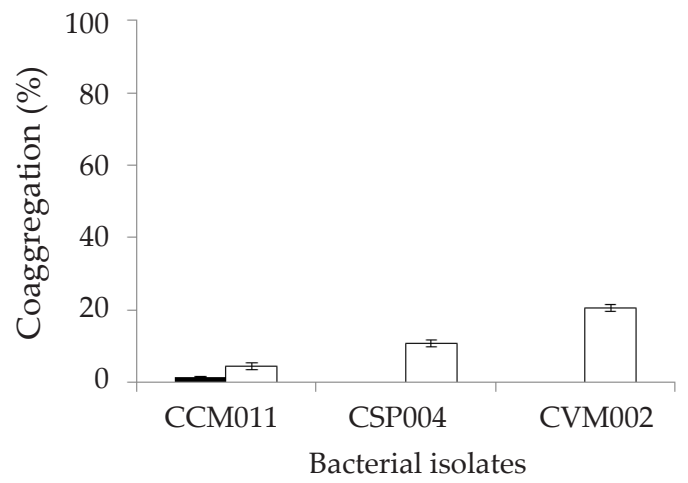

Figure 2. Coaggregation ability of LAB isolates $(n=3)$ and indicator bacteria (E. coli $(\square)$ and S. enteritidis ( $\square)$ ).
E. coli with CSP004 and CVM002 isolates (Figure 2). In addition, coaggregation of LAB isolates with $S$. enteritidis was $4 \%-20 \%$ (Figure 2).

Antibiotic resistance assay of the LAB isolates showed that there was no resistant to examined antibiotics, but each isolate at least showed intermediate status to one of antibiotics. Isolates of CCM011, CSP004, and CVM002 were detected to be intermediate resistant to lincomycin, tetracyclin and erythromycin, respectively.

\section{Identification of Selected LAB Isolates}

Genotypically, the three selected LAB isolates i.e. CCM011, CSP004 and CVM002 were identified based on sequence analysis of $16 \mathrm{~S}$ rRNA gene and showed that DNA fragments of amplification products were about $1500 \mathrm{bp}$ (Figure 3). The analysis of 16S rRNA gene of isolates has been successfully sequenced, aligned and compared. The isolates were identified as Lactobacillus salivarius with sequences similarity 99\% (GenBank accession number, KC020621.1 and AB612967.1). Phylogenetic tree based on 16S rRNA gene sequences analysis showed that the isolates were clustered in one group (Figure 4). L. salivarius was known as the indigeneous strain of gastrointestinal tract and has probiotic properties (Nouri et al., 2010, Raftis et al., 2011).

Phenotypic identification based on carbohydrate fermentation assay by the API $50 \mathrm{CH}$ system showed that the three selected isolates were closely related to $L$. salivarius with a $99.9 \%$ similarity. This result confirmed genotypic identification. However, there were traits differences in consuming various carbon sources among the LAB isolates. CSP004 and CVM002 isolates showed relatively similar carbon fermentation profiles, however they had different carbon fermentation profiles from CCM011 isolate. CCM011 isolate was lack ability to use d-galactose, d-lactose, d-mellibiose, and d-raffinose as carbon sources. L. salivarius CCM011 lacked ability to use galactose and lactose. It was possible that CCM011 did not have an intracellular transport system to take up the lactose and cannot produce the enzyme $\beta$-galactosidase/ lactase.

Meanwhile, there were traits differences between CSP004 and CVM002 isolates. CVM002 could use rhamnose, xilitol and arabitol for carbon sources, however CSP004 could use inositol for carbon source (Table 6).

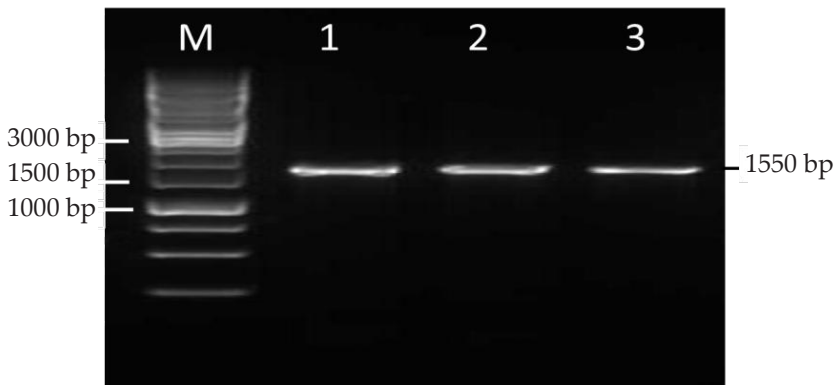

Figure 3. Agarose gel (1\%) analysis of PCR amplification products of $16 \mathrm{~S}$ rRNA gene of lactic acid bacteria isolates. $\mathrm{M}=$ Molecular marker (1 kb ladder), lane 1= CSP004; lane $2=\mathrm{CCM} 011$ and lane $3=\mathrm{CVM} 002$ isolate 


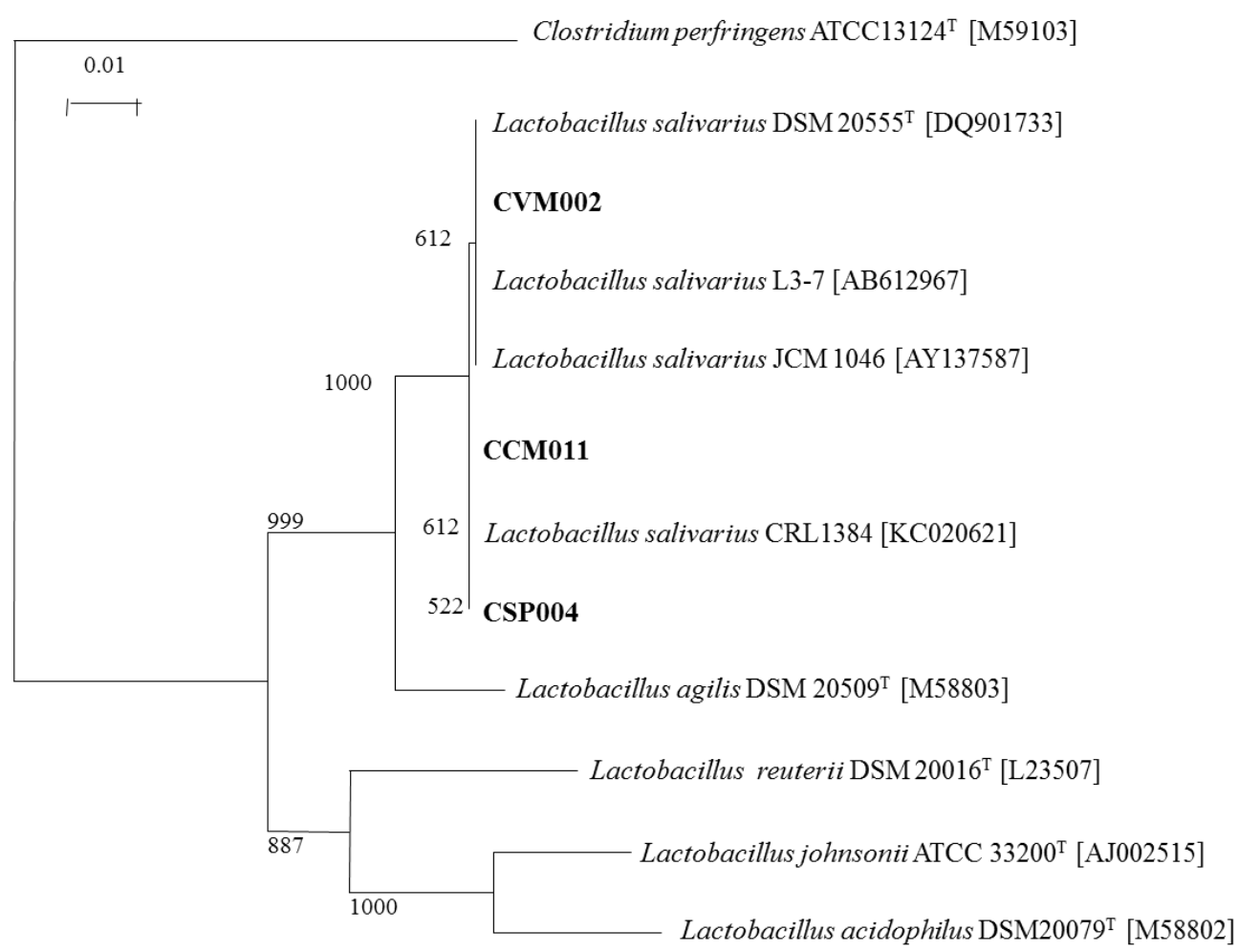

Figure 4. Phylogenetic tree derived from fulllength of $16 \mathrm{~S}$ rDNA sequences analysis of LAB isolates showing the position of Lactobacillus salivarius CCM011, CSP004 and CVM002 among selected lactobacilli. The tree was generated by the neigbour-joining method and Clostridium perfringens was used as the out group. Bootstrap value based on 1000 replications are given at nodes. Bar 0.01 substitutions per nucleotide position. Accession numbers of sequences obtained from NCBI database.

\section{CONCLUSION}

The three selected LAB isolates (CCM011, CSP004, and CVM002 demonstrated antimicrobial activity against E. coli and S. enteritidis, resistance to low $\mathrm{pH}$, strong hydrophobicity to hydrocarbon and coaggregation of inter-LAB isolates, but weak coaggregation with the bacterial pathogens and susceptible to examined antibiotics. The isolates were identified as Lactobacillus salivarius with $99 \%$ similarity. However, there were different characteristics of sugar fermentation profiles among the isolates. Considering the characteristics above, the isolates may be used as probiotics in poultry farm. In vivo assay will be required for evaluation of the isolates as a probiotic supplement in chicken.

\section{ACKNOWLEDGEMENT}

This work was supported by the scholarship grants from Directorate General of Higher Education, Ministry of Education and Culture, Indonesia, and Research Center for Biology-Indonesian Institute of Sciences, and the SATREPS JST-JICA projects.

\section{REFERENCES}

Alakomi, H. L., E. Skytta, M. Saarela, T. Mattila-Sandholm, K. Latva-Kala, \& I. M. Helander. 2000. Lactic acid permeabilizes gram-negative bacteria by disrupting the outer mem- brane. Appl. Environ. Microb, 66:2001-2005. http://dx.doi. org/10.1128/AEM.66.5.2001-2005.2000

Corcionivoschi, N., D. Drinceanu, I. M. Pop, D. Stack, L. Stef, C. Julean, \& B. Bourke. 2010. The Effect of Probiotics on Animal Health. Anim. Sci. and Biotechnol. 43:35-41.

Dumonceaux, T. J., J. E. Hill, S. M. Hemmingsen, \& A. G. Van Kessel. 2006. Characterization of intestinal microbiota and response to dietary virginiamycin supplementation in the broiler chicken. Appl. Environ. Microbiol., 72:2815-2823. http://dx.doi.org/10.1128/AEM.72.4.2815-2823.2006

FAO/WHO - Food and Agriculture organization of the United Nations/World Health Organization (2002): Guidelines for evaluation of probiotics in food. Available at: http:// www.who.int/foodsafety/fs_management/en/probiotic_ guidelines.pdf

Felsenstein, J. 1985. Confidence limits on phylogenies : an approach using the bootstrap. Evolution 39: 783-791.

Gaggia, F., P. Mattarelli, \& B. Biavati. 2010. Review: Probiotics and prebiotics in animal feeding for safe food production. Int. J. Food Microbiol. 141: S15-S28. http://dx.doi. org/10.1016/j.ijfoodmicro.2010.02.031

Guerin-Danan, C., A. Andrieux, \& O. Szylit. 1999. Storage of Intestinal bacteria in samples frozen with glycerol. Microbiol. Ecol. in Health \& Disease 11:180-182. http://dx.doi. org/10.1080/089106099435772

Heravi, R. M., H. Kermanshahi, M. Sankian, M. R. Nassiri, A. H. Moussavi, L. R. Nasiraii, \& A. R. Varasteh. 2011. Screening of lactobacilli bacteria isolated from gastrointestinal tract of broiler chickens for their use as probiotic. African J. Microbiol. Res. 5:1858-1868.

Iniguez-Palomares, C., R. Perez-Morales, \& E. Acedo-Felix. 2007. Evaluation of probiotic properties in Lactobacillus isolated from small intestine of piglets. Microbiol. 49:46-54. 
Istiqomah, L., S. N. Hayati, E. Damayanti, H. Julendra, A. A. Sakti, \& T. Untari. 2013. Performance and Meat Quality of Broilers Infected with Escherichia coli and Administered with Bio Additive, Probiotic, and Antibiotic. Med.Pet. 36:14-20. http://dx.doi.org/10.5398/medpet.2013.36.1.14

Konings W. N., J. S. Lolkema, H. Bolhuis, H. W. Van Veen, B. Poolman, \& A. J. M. Driessen. 1997. The role of transport processes in survival of lactic acid bacteria. Antonie van leeuwenhoek 71:117-128. http://dx.doi.org/10.1023/ A:1000143525601

Musikasang H., N. Sohsomboon, A. Tani, \& S. Maneerat. 2012. Bacteriocin-producing lactic acid bacteria as a probiotic potential from Thai indigenous chickens. Czech J Anim. Sci., 57: 137-149.

Nataamijaya, A. G. 2010. Pengembangan potensi ayam lokal untuk menunjang peningkatan kesejahteraan petani. J. Litbang. Pertan. 29: 131-138.

Nouri, M., F. Rahbarizadeh, D. Akhmadvand, F. Moosakhani, E. Sadeqzadeh, S. Lavasani, \& V. K. Vishteh. 2010. Inhibitory effects of Lactobacilus salivarius and Lactobacillus crispatus isolated from chicken gastrointestinal tract on Salmonella enteritidis and Escherichia coli growth. Iranian J. Biotechnol. 8: 32-37.

Palacios, M. C., M. Haros, Y. Sanz, \& C. M. Rosell. 2008. Selection of lactic acid bacteria with high phytate degrading activity for application in whole wheat breadmaking. LWT- Food Sci. Technol. 41:82-92. http://dx.doi.org/10.1016/ j.lwt.2007.02.005

Pelinescu, D. R., E. Sasarman, M. C. Chifiriuc, I. Stoica, A. M. Nohit, I. Avram, F. Serbancea, \& T. V. Dimov. 2009. Isolation and identification of some Lactobacillus and Enterococcus strains by a polyphasic taxonomical approach. Romanian Biotech. Lett. 14:4225-4233.

Raftis, E. J., E. Salvetti, S. Torriani, G. E. Felis \& P. W. O'Toole. 2011. Genomic diversity of Lactobacillus salivarius. Appl. Environ. Microbiol. 77:954-965. http://dx.doi.org/10.1128/ AEM.01687-10
Raghavendra, P. \& P. M. Halami. 2009. Screening, selection and characterization of phytic acid degrading lactic acid bacteria from chicken intestine. Int. J. of Food Microbiol. 133:129-134. http://dx.doi.org/10.1016/j.ijfoodmicro.2009.0 5.006

Sartika, T., S. Sulandari, \& M. S. A. Zein. 2011. Selection of Mx gene genotype as genetic marker for Avian Influenza resistance in Indonesia native chicken. BMC Proceedings 5:S37.

Sofyan, A., M. Angwar, H. Herdian, E. Damayanti, L. Istiqomah, A. Febrisiantosa, H. Julendra, M. H. Wibowo, \& T. Untari. 2012. Performance Enhancement and Immunity Profile of Broiler Treated Feed Additive Containing Lactic Acid Bacteria and Ganoderma lucidum. Med. Pet. 35: 201206. http://dx.doi.org/10.5398/medpet.2012.35.3.201

Sulandari S., M. S. A. Zein, D. Astuti, \& T. Sartika. 2009. Genetic polymorphisms of the chicken antiviral Mx gene in a variety of Indonesian indigenous chicken breeds. J Vet. 10: $50-56$

Taheri, H. R., H. Moravej, F. Tabandeh, M. Zaghari, \& M. Shivazad. 2009. Screening of lactic acid bacteria toward their selection as a source of chicken probiotic. Poult. Sci. 88:1586-1593. http://dx.doi.org/10.3382/ps.2009-00041

Tannock, G. W. 1999. Identification of Lactobacilli and Bifidobacteria. Current Issues Molec. Biol. 1: 53-64

Torshizi, M. A. K., S. H. Rahimi, N. Mogjani, S. Esmaeilkhanian, \& J. L. Grimes. 2008. Screening of indigenous strains of lactic acid bacteria for development of a probiotic for poultry. Asian-Australian J Anim. Sci. 21:1495-1500. http:// dx.doi.org/10.5713/ajas.2008.80081

Zhang, M., B. Liu, Y. Zhang, H. Wei, Y. Lei, \& L. Zhao. 2007. Structural shifts of mucosa-associated lactobacilli and Clostridium leptum subgroup in patients with ulcerative colitis. J. Clin. Microbiol. 45:496-500. http://dx.doi. org/10.1128/JCM.01720-06 